\title{
Estimation of Biomass Availability in Panglao Island Using SENTINEL-2 MSI
}

\author{
W.N. Galang *(**)†, I.D.F. Tabañag*** and M.E. Loretero $* * * *$ \\ *School of Engineering, University of San Carlos, Cebu City, Cebu, Philippines \\ **College of Engineering and Computer Studies, Holy Name University, Tagbilaran City, Bohol, Philippines \\ ***Department of Chemical Engineering, University of San Carlos, Cebu City, Cebu, Philippines \\ ****Department of Mechanical and Manufacturing Engineering, University of San Carlos, Cebu City, Cebu, Philippines \\ †Correspondence: W.N. Galang; naborgalang@gmail.com
}

\section{Nat. Env. \& Poll. Tech.}

Website: www.neptjournal.com

Received: $18-10-2020$

Revised: 17-01-2021

Accepted: 22-01-2021

Key Words:

Biomass assessment Geographical information system (GIS)

Normalized difference vegetation index (NDVI)

Remote sensing (RS)

Theoretical energy potential

\section{ABSTRACT}

Remote Sensing (RS) technology using SENTINEL-2 Multispectral Instrument (MSI) imagery was used in the estimation of residual biomass' available energy potential. The estimation was done in Panglao Island, within the province of Bohol, Philippines. Estimation of biomass availability was processed using Geographical Information System (GIS) software incorporating the calculation of Normalized Difference Vegetation Index (NDVI) to extract information on land resources and its spatial distribution. It was found that the majority of vegetation cover on the island is in the form of perennial woody plants and coconut trees. Coconut production on the island of Panglao contributed $1.26 \%$ of the total cultivation area for the province based on processed captures of Sentinel-2 imagery. The residue concentration amounted to 2,865 tons of coconut residues based on the RPR method. This amount of residues can be translated to $52.92 \mathrm{TJ}$ of theoretical energy potential. The result of this study may serve as a baseline for the locality to consider the utilization of agricultural residues such as coming from coconut trees to support the use of indigenous resources for energy generation.

\section{INTRODUCTION}

In the Philippines, the problem of electricity demand is expected to continually increase by end of 2040. Biomass residues from agricultural crops, plantations, or residual forest products can be used as an alternate source. As of 2016, biomass accounted for 25.5 percent of the country's indigenous energy source. The household sector accounted for the majority of biomass consumption. It is the most preferred fuel among households because of its abundance, accessibility, and affordability, particularly in rural areas. Similarly, biomass gradually increased its contribution to the power industry, with its fuel input to electricity generation more than doubling from 2015 to 2016. Despite the Department of Energy's (DOE) order dated May 2018 to ensure access to electricity for areas that remain unserved and underserved by distribution companies and electric cooperatives, there are still rural areas without electricity.

The term biomass refers to any organic material derived from plants. Biomass comes from green plants through photosynthesis that converts sunlight into plant material. Biomass resource can be considered as an organic material, in which solar energy is stored in chemical bonds. When the bonds between adjacent carbon, hydrogen, and oxygen molecules are broken by digestion, combustion, or decomposition, these substances release the stored, chemical energy (McKendry, 2002). Biomass basically can be divided into three major groups, wood biomass, non-wood biomass, and secondary fuels (Calle et al. 2007).

Panglao is an island located in the Central Visayas region of the Visayas island group and bounded by the Bohol Sea in the north of south-central Philippines. The power plants located in Leyte and Cebu through Leyte-Bohol Transmission Interconnection is the prime power supplier of Bohol including that of the island of Panglao. In 2015, power plants outside of Bohol supplied $68.86 \mathrm{MW}$, or 89 percent, of the province's peak demand through the Leyte-Bohol Interconnection, while the remaining 8.4 MW or 11 percent is collectively supplied by the three mini-hydro plants inside Bohol. According to Bohol's projected energy demand, total energy consumption was $344.66 \mathrm{GWh}$ in 2015 and is expected to increase to $440.10 \mathrm{GWh}$ by 2020 (Provincial Planning and Development Office, 2018).

The island of Panglao has sources of potential energy from agricultural products waste. The potential agricultural product wastes that can be utilized as an alternative energy source are coconut husks and shells. The underlying issue, 
however, is a lack of certainty about the entire availability and potential of coconut residues on the island. An assessment of biomass availability for bioenergy as an initial step is necessary. Several factors should be identified and addressed, including land resources, the spatial distribution of resources, and geographic factors of the resources, to assess the spatial distribution and quantity of residual biomass accurately.

Different types of satellite imageries can be used in identifying agricultural crop areas, one of the initial processes involved in the assessment. Aside from locating residue sources, these images are also used in generating agricultural maps. These maps are used as the primary input data in the estimation of biomass availability in a given area.

The rapid development of remote sensing (RS) has led to increasing usage of high-resolution data regarding space, time, and spectrum to extract vegetation information and improve parameters, which enables biomass estimation with increased accuracy. The instruments used for RS have a wide range of coverage, from airborne cameras to sensors onboard satellites. The development of RS methods provides a better understanding of the relationship between leaf reflectance changes and physio-ecological factors of vegetation. Available satellite, aerial, and ground remote sensing platforms offer different spatial- and temporal-resolution information for energy crop management.

The main reason for using RS data, apart from the ability to cover large areas, is its ability to offer useful information on crop activity and health in a practical, non-destructive way (Ahamed et al. 2013, Moulin et al.1998, Onojeghuo et al. 2018). The ground-based RS data excel in establishing the calibration model for biomass yield prediction and providing references for aerial and satellite RS which can cover a wide range of biomass production systems (Ahamed et al. 2011, Ali et al. 2016).

This study considers the advantage of RS wide range coverage. The remote sensing spatio-temporal data provided by SENTINEL-2 Multispectral Instrument (MSI) samples 13 spectral bands. There are four bands at 10 meters, six bands at 20 meters, and three bands at 60 meters spatial resolution images. These bands are being used in the analysis of land cover and crop activity.

This study aims to come up with an assessment approach considering the unavailability of data to establish information on biomass resource estimation by the usage of remote sensing imagery. The results provide a baseline of information on biomass resources available in Panglao Island using the remote sensing images from SENTINEL-2 Multispectral Instrument (MSI). It could be an initial step for promoting the use of indigenous resources for energy generation.

\section{MATERIALS AND METHODS}

The study was conducted within the scope of Panglao Island. It has an area of $91.12 \mathrm{~km}^{2}$ (35.18 sq mi) see Fig. 1. The island is within the province of Bohol and comprises two municipalities, Dauis and Panglao, respectively. Panglao Island is located southwest of Bohol and southeast of Cebu. It belongs to the fourth climatic type, which is characterized by rainfall more or less evenly distributed throughout the year. The dry season starts from January to May while the rest of the year is generally wet. Rainfall distribution is influenced by the prevailing air streams, the intertropical convergence zone (ITCZ), and the island's topography. The study sites were more of a $90 \%$ level to nearly level topography, $10 \%$ rolling to the undulating slope, and about $5 \%$ rolling to moderately

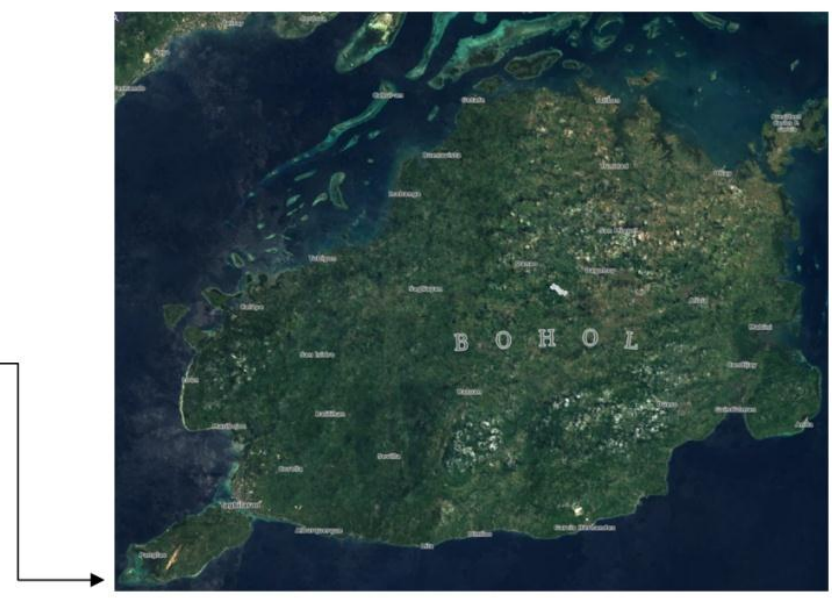

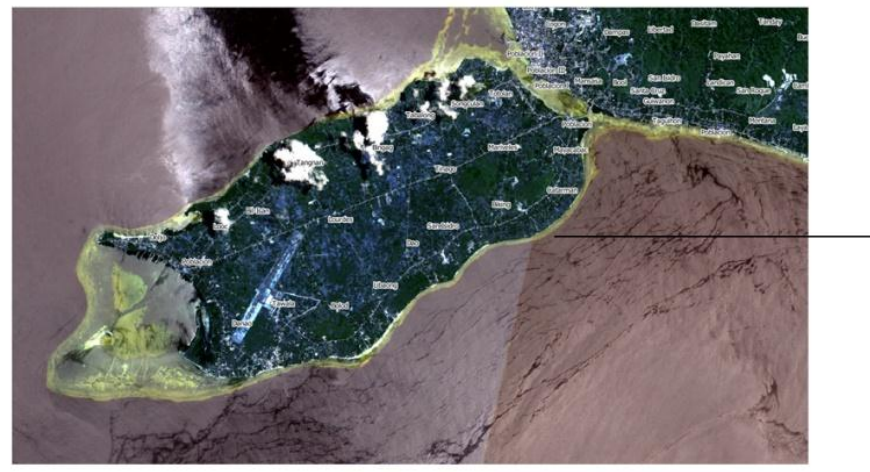

Fig. 1: Area of study, the island of Panglao. 
steep. In general, the location of Panglao has a terrain that ranges from plain, hilly to mountainous. The island itself is made of Maribojoc limestone, the youngest of the limestone units found in the western area of the province.

The acquired data taken from SENTINEL-2, with its mission coverage and high revisit frequency provides generation of geoinformation from local to international scales. This data may be modified and adapted by users for application in spatial planning and monitoring of the environment, water, forest, land carbon, resources, and global crop. The fundamental level of Sentinel-2 MSI products is provided in granules of a fixed size. For ortho rectified products, Level-1C and Level-2A are the images divided into $100 \mathrm{~km}$ tiles in UTM/WGS84 projection. The availability of data for general users is given in the Level-1C and Level-2A products.

\section{Band Combinations Using the Spatio-Temporal Images}

Initially, the study involved the use- of Sentinel-2 images using the QuantumGIS, a free and open-source cross-platform desktop application that supports viewing, editing, and analysis of geospatial data based from the QGIS Official Website. The selection of specific bands from the Sentinel-2 image via disabling the other bands enables to identify the requirement of the study area, indicating the specific location in the search parameters including the search date and filters to be applied to obtain the adjusted symbology for the study area. The adjusted symbology was from Sentinel-2 bands: Band 2- Blue, Band 3- Green, and Band 4-Red with 10m resolution with tile number T51PWL taken as of May 10, 2019, see Fig. 2 and Fig. 3.

The basis to determine the density of greenness of the Earth's surface, satellites measure the distinct colors or wavelengths of visible and near-infrared sunlight reflected by the plants. Green plants look green because chlorophyll preferentially absorbs light, certain wavelengths of this spectrum are absorbed and other wavelengths are reflected.

The NDVI is one of the most common indices widely applied for monitoring vegetation dynamics at regional and global scales (Vrieling et al. 2013, Zhu et al. 2013). NDVI was preferred as it is a numerical indicator that can be used as a proxy for plant biomass (Dube et al. 2014). This index varies between -1 and 1 in which the values less than zero during the growing season indicate no vegetation cover while values more than zero in the growing season describe

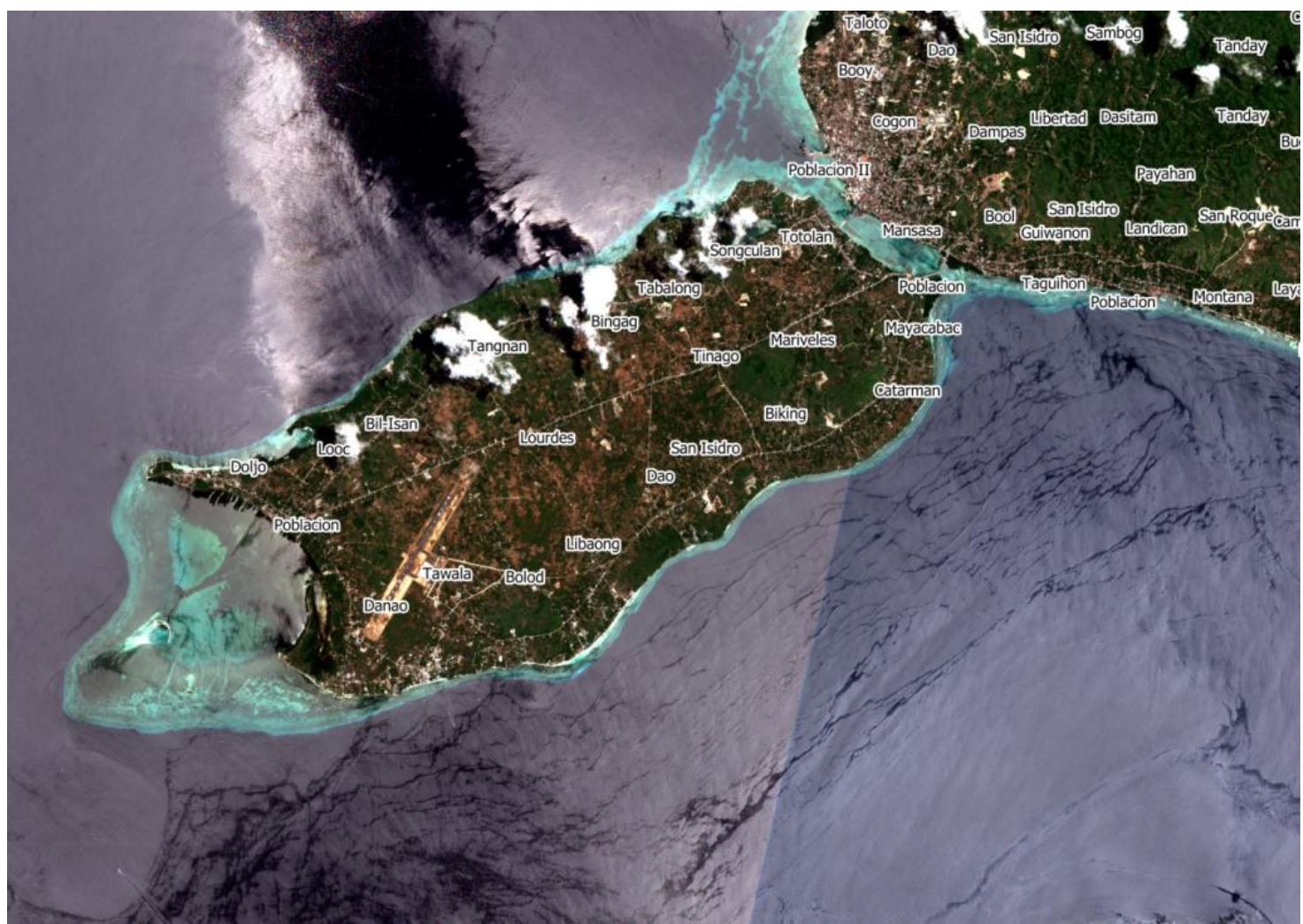

Fig. 2: Sentinel-2 image of Panglao Island with adjusted symbology. 


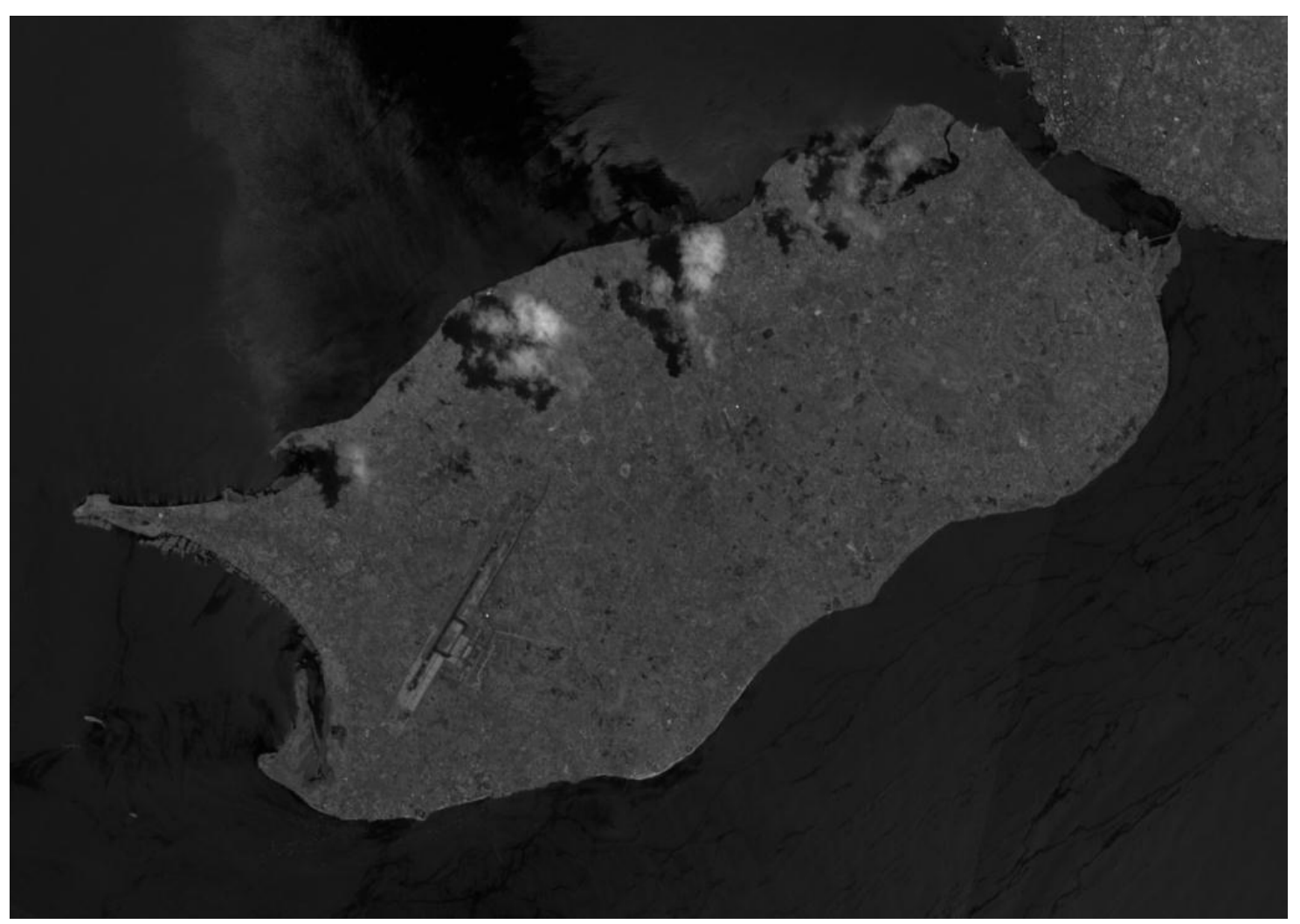

Fig. 3: Panglao Island with band 4 and band 8 .

available vegetation cover. The NDVI was calculated using the following formula (Choubin \& Malekian 2017):

$$
N D V I=(N I R-R e d) /(N I R+R e d)
$$

where $N D V I$ is the Normalized Difference Vegetation Index, $N I R$ is a reflection in the Near Infrared band and Red is a reflection in the red band.

The generated vegetation cover from NDVI calculation is the basis to define the cultivation area related to the plantation density of the crop under study. The measurement forms part of the biomass residue calculation.

\section{Biomass Residue Calculation}

The basic data necessary to perform any assessment about available agricultural residues include the type of crop and crop surface, crop yield, plantation density, and residue to product ratio. A sufficient number of average values referred to the last harvests performed in the area were used to ensure data representation.

One of the most common methodologies to assess residual biomass is to consider the crop yield and a residue to product ratio, previously estimated at a regional or local level, using the following equation:

$$
\operatorname{Pr}=Y * R P R
$$

where, $\operatorname{Pr}$ corresponds to the potential crop residue produces (t.year $^{-1}$ ); $Y$ corresponds to the crop yield by the locality (t.year $^{-1}$ ); RPR corresponds to the residue-to-product ratio, which relates the generated crop residue to the total crop produced.

The estimation is considered a Residue-to-Product Ratio (RPR). This method uses an average value of residue generation (Koopmans \& Koopenjan 1997). The significant differences between RPR's used in different studies depend on several factors, mostly caused by variations in weather, crop type grown, water availability, soil fertility, farming practice, among others. The RPR used in this study considered the average ratios from related literature.

The RPR method of residue estimation considered the possibility of varying productiveness depending on the geographic distribution of plantations. This method is the most commonly used to estimate the biomass residue production of agricultural crops because the RPR method considers the crop species, harvest season, cultivation methods, among 
other factors, representing the reality of the production area (Rahman et al. 2012, Voivontas et al. 2001).

\section{Theoretical Energy Potential Calculation}

$$
T E P=\operatorname{Pr} * L H V
$$

where, TEP corresponds to the Theoretical Energy Potential; $\operatorname{Pr}$ relates to the potential crop residue produces ( year $^{-1}$ ); $L H V$ shows the lower heating value of the plant as $\mathrm{MJ} \mathrm{kg}^{-1}$.

Theoretical biomass energy potential was calculated in previous literature in similar ways (Milhau \& Fallot 2013, Ozturk \& Bascetincelik 2006, Riva et al. 2014, Okello et al. 2013, Iye \& Bilsborrow 2013, Singh 2015).

The methodology was applied to the island of Panglao. The biomass distribution was computed using Eq(2) with parameters from Table 1. It utilizes the satellite image captures from Sentinel-2 to determine the coconut crop area and be able to determine the yield in relation to the statistical data through the Census of Agriculture and Fisheries 2017 record from the Philippine Statistics Authority August 2019 report.

The computation of residues on the island allows for the calculation of theoretical energy potential using $\mathrm{Eq}(3)$. The values for the lower heating value of coconut husk and shell were based on related literature indicated in Table 1.

The Sentinel-2 Multispectral Instrument (MSI) image provides a high spatial resolution that aids the band classification process to define the parameters for calculating the vegetation cover of the island. Since crop statistical data with respect to each barangay or village on the island is unavailable, the images captured by Sentinel-2 gathered since 2015 recorded the latest possible land cover changes.

The distinct colors or wavelengths of visible and near-infrared sunlight reflected by the plants must be observed to determine the density of green on a certain land area. The pigment in plant leaves, chlorophyll, strongly absorbs visible light from 0.4 to $0.7 \mu \mathrm{m}$ for use in photosynthesis. On the

Table 1: Overview of the RPR and LHV used in this study.

\begin{tabular}{|lll|}
\hline Parameters & \multicolumn{2}{c|}{ Coconut Residues } \\
\cline { 2 - 3 } & Husk & Shell \\
\hline RPR ( $\left.\mathrm{t}_{\text {residue }} / \mathrm{t}_{\text {product }}\right)$ & 1.60 & 0.65 \\
& 0.419 & 0.12 \\
LHV $(\mathrm{MJ} / \mathrm{kg})$ & 18.62 & 18.09 \\
\hline
\end{tabular}

Residue-to-product ratio based on (Massaquoi 1990, Bhattacharya 1993, Ryan 1991, Singh 2008) other hand, the cell structure of the leaves strongly reflects near-infrared light from 0.7 to $1.1 \mu \mathrm{m}$. Hence, the more leaves a plant has, the more these wavelengths of light are affected, respectively. Fig. 4 indicates the NDVI calculated for Panglao Island that ranges from -0.77 to 0.86 .

\section{Biomass Residue Availability from Agricultural Abundance}

Calculations of NDVI from $\mathrm{Eq}(1)$ for a given pixel always result in a number that ranges from minus one $(-1)$ to plus one $(+1)$. However, no green leaves give a value close to zero. A zero means no vegetation and close to $+1(0.8-0.9)$ indicates the highest possible density of green leaves. Fig. 5 provides an overview of vegetation cover in Panglao Island.

\section{RESULTS AND DISCUSSION}

The existing energy infrastructures in Bohol do not use biomass even though securing energy and power from different sources is a priority set by recent policies. Given the availability and potential of biomass, especially the crops residues, residual biomass can be a significant source of energy and power in the province. The result of the vegetation cover map as processed in GIS software leads to identifying areas with residual biomass in the form of coconut husk and shells.

The summary of vegetation cover for respective barangays or villages is listed in Table 2 . The vegetation cover for a potential biomass source accounts for 12.62 percent of Panglao Island's total land area. The majority of vegetation cover on the island is in the form of perennial woody plants and coconut trees. Due to municipal policy on tourism and the identification of built-up areas, there are areas on the island with a plus one value for vegetation cover that was not included in the calculation for potential crop residue. The island of Panglao is well-known for its white-sand beaches, and while there are tourist zones with coconut trees, they are not meant for coconut production but rather for tourism. Nevertheless, there are several areas with an abundance of forest trees, shrubs, and agricultural crops. Identified areas with vegetation cover were field validated for the agricultural crop in the form of coconut presence and abundance for potential residue collection.

The coconut trees on the island of Panglao covered $1.26 \%$ of the total cultivation area of the province based on the vegetation cover of Sentinel-2 imagery. In 2017, coconut yield potentially reached 2,054 metric tons with a residue concentration amounting to 2,865 tons based on the RPR method. This amount of residues can be translated to 52.92 $\mathrm{TJ}$ of theoretical energy potential. (see Table 3 ). 


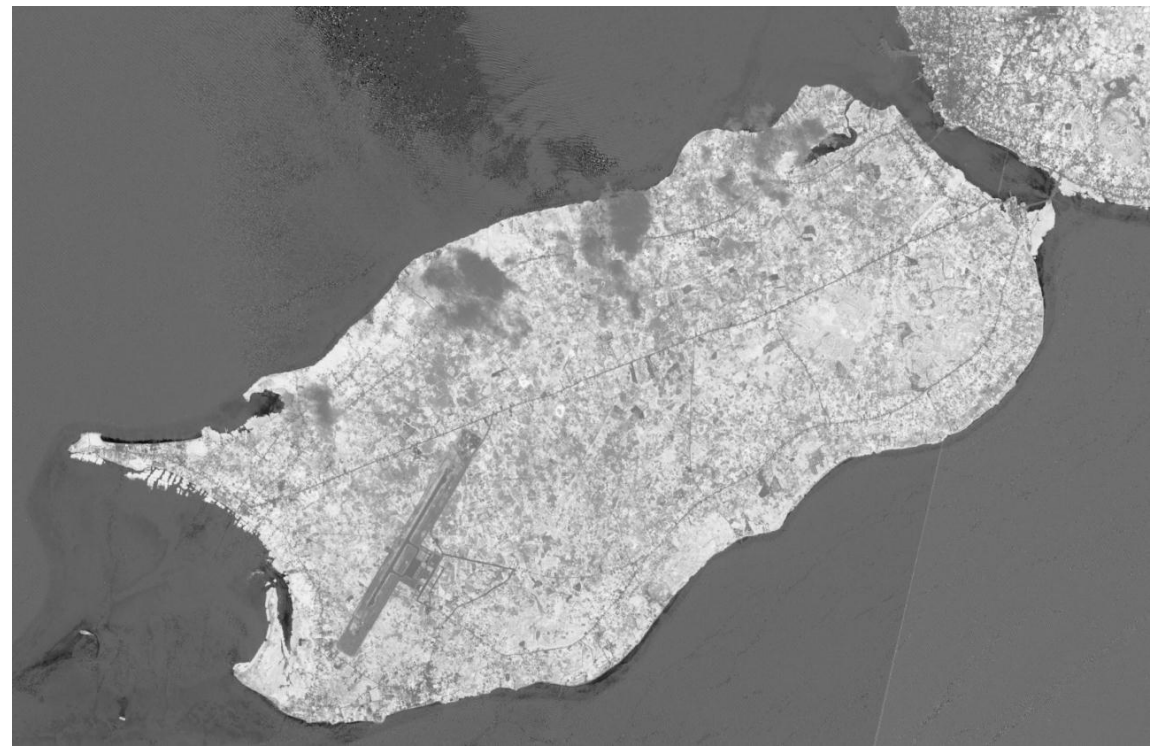

Fig. 4: Panglao island NDVI, ranges from -0.77 to 0.86 .

\section{Estimation of Biomass Residues and Energy Potential in Panglao Island}

The island has the potential to produce 2073.74 tons of coconut husk and 790.88 tons of coconut shell in a cultivation area of 444 hectares. Considering the average energy content for coconut, the theoretical energy generation potential from coconut residues turned out to be 52.92 terajoules. The contributions of different barangays or villages for the coconut residues to theoretical energy generation are summarized in Table 3, considering the fact that all of the residual biomass is recoverable. According to the analysis, using unused residues

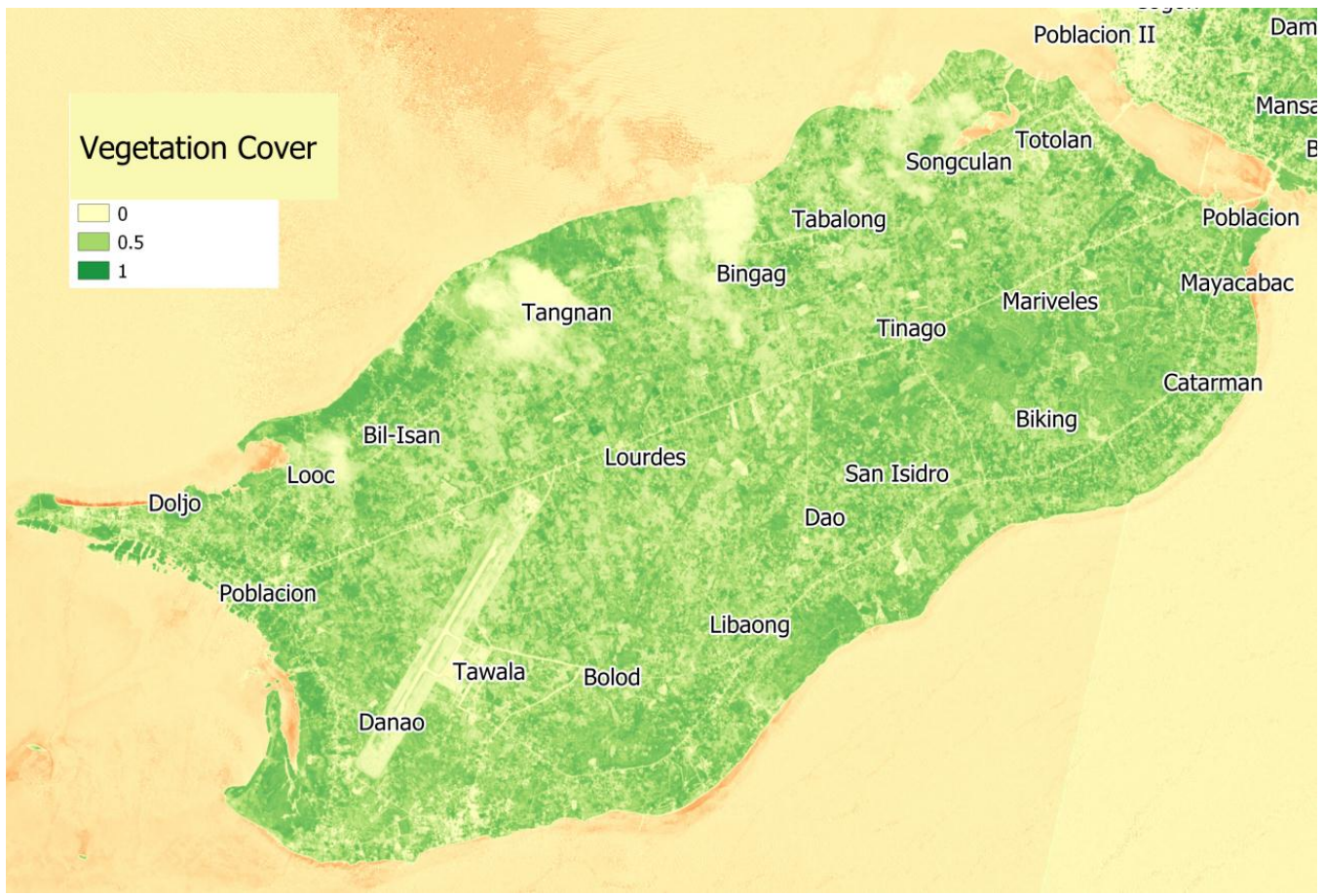

Fig. 5: Panglao island vegetation cover. 
from agriculture crop sources can generate potential energy with 100 percent waste recovery. However, if the recovery rate is lower, the amount of energy that may be produced is proportionately lower. It must be noted that the amount of energy is mostly based on available biomass resources which are currently unutilized.

The amount of theoretical energy potential recovered is still low compared to the demand of 33,553 total population of Panglao in the 2015 Bohol Census. However, the island of Panglao has several areas with an abundance of coconut trees being a landmass separated from the mainland of the province. The surrounding coconut trees on the island provide the potential for renewable energy when its residues are fully collected and utilized for bioenergy.

\section{CONCLUSION}

The resource assessment approach evaluated the energy potential of agricultural residues using Sentinel-2 MSI images. It has a resolution of 10 to $60 \mathrm{~m}$ in the visible, near-infrared, and short-wave infrared spectral zones. The captured images include 13 spectral channels, ensuring that differences in vegetation status and temporal changes. The unavailability of data to establish information on biomass resource estimation was bridged by the usage of remote sensing imagery, including the advantage of wide range coverage.

Biomass availability assessment accounts for an overview of the distribution and abundance of biomass resources that can be explored for electricity generation. An agricultural residue is an indigenous form of biomass residue that is widely available for waste to energy utilization. The increasing energy demand shall be sustained when alternative options for renewable and sustainable energy sources are assessed for its availability. This study may serve as a baseline for creating policies and strategies of the local government to fully utilize the potential of the agricultural sector.

Table 2: Estimation of coconut distribution areas in Panglao.

\begin{tabular}{|ll|}
\hline Name of Barangay & Area $($ sqm $)$ \\
\hline Bil-Isan & 1121426.75 \\
Danao & 1313519.74 \\
Doljo & 464776.26 \\
Looc & 500944.16 \\
Songculan & 98922.84 \\
Tabalong & 21345.7 \\
Totolan & 919853.53 \\
\hline
\end{tabular}

Estimation based on attribute data generated from vegetation cover
Table 3: Panglao coconut bioenergy potential.

\begin{tabular}{|c|c|c|c|}
\hline \multirow[t]{2}{*}{$\begin{array}{l}\text { Name of } \\
\text { Barangay }\end{array}$} & \multicolumn{2}{|c|}{$\begin{array}{l}\text { Potential Crop } \\
\text { Residue }\left(\text { t year }^{-1}\right)\end{array}$} & $\begin{array}{c}\text { Theoretical Energy } \\
\text { Potential (TJ) }\end{array}$ \\
\hline & Husk & Shell & Coconut Residues \\
\hline Bil-Isan & 523.68 & 199.72 & 13.36 \\
\hline Danao & 613.38 & 233.93 & 15.65 \\
\hline Doljo & 217.04 & 82.77 & 5.54 \\
\hline Looc & 233.93 & 89.22 & 5.97 \\
\hline Songculan & 46.19 & 17.62 & 1.18 \\
\hline Tabalong & 9.97 & 3.80 & 0.25 \\
\hline Totolan & 429.55 & 163.82 & 10.96 \\
\hline
\end{tabular}

Estimation based on $P r$ and TEP calculations

\section{ACKNOWLEDGMENT}

This study was supported by the Department of Science and Technology, Science Education Institute under the Engineering Research and Development for Technology program. We are grateful to DOST for the financial support given and the University of San Carlos, School of Engineering for the accessibility and use of available facilities.

\section{REFERENCES}

Ahamed, T., Tian, L., Ryozo, N. and Takigawa, T. 2013. Remote sensing applications of estimating biomass for energy crops: Development of ground-based sensing systems. Remote Sens- Tech. Appl. Technol., 6(1): 31-53.

Ahamed, T., Tian, L., Zhang, Y. and Ting, K.C. 2011. A review of remote sensing methods for biomass feedstock production. Biomass Bioenerg., 35(7): 2455-2469. https://doi.org/10.1016/j.biombioe.2011.02.028.

Ali, I., Cawkwell, F., Dwyer, E., Barrett, B. and Green, S. 2016. Satellite remote sensing of grasslands: From observation to management. J. Plant Ecol., 9(6): 649-671. https://doi.org/10.1093/jpe/rtw005.

Calle, F, Rosillo, P, Groot, S.L.H. and Woods, J. 2007. The Biomass Assessment Handbook: Bioenergy For A Sustainable Environment. Earthscan Publications Ltd, London, UK.

Choubin, B. and Malekian, A. 2017. Combined gamma and M-test-based ANN and ARIMA models for groundwater fluctuation forecasting in semiarid regions. Environ. Earth Sci., 76(15): 1-10. https://doi. org/10.1007/s12665-017-6870-8.

Dube, T., Gumindoga, W. and Chawira, M. 2014. Detection of land cover changes around Lake Mutirikwi, Zimbabwe, based on traditional remote sensing image classification techniques. Afr. J. Aquat. Sci., 39(1): 8995. https://doi.org/10.2989/16085914.2013.870068.

Iye, E. L. and Bilsborrow, P. E. 2013. Assessment of the availability of agricultural residues on a zonal basis for medium- to large-scale bioenergy production in Nigeria. Biomass Bioenerg., 48: 66-74. https:// doi.org/10.1016/j.biombioe.2012.11.015.

Koopmans, A. and Koopenjan, J. 1997. Agricultural and Forest ResiduesGeneration, Utilization, and Availability. Reg. Consul. Modern Appli. Biomass Energ., 9: 23.

McKendry, P. 2002. Energy production from biomass (Part 1): Overview of biomass. Bioresour Technol, 83(1): 37-46. https://doi.org/10.1016/ s0960-8524(01)00118-3. 
Milhau, A. and Fallot, A. 2013. Assessing the potentials of agricultural residues for energy: What the CDM experience of India tells us about their availability. Energy Policy, 58: 391-402. https://doi.org/10.1016/j. enpol.2013.03.041.

Moulin, S., Bondeau, A. and Delecolle, R. 1998. Combining agricultural crop models and satellite observations: from field to regional scales. Int. J. Remote Sens., 19: 1021-1036.

Okello, C., Pindozzi, S., Faugno, S. and Boccia, L. 2013. Bioenergy potential of agricultural and forest residues in Uganda. Biomass Bioenerg., 56: 515-525. https://doi.org/10.1016/j.biombioe.2013.06.003.

Onojeghuo, A.O., Blackburn, G.A., Huang, J., Kindred, D. and Huang, W. 2018. Applications of satellite 'hyper-sensing' in Chinese agriculture: Challenges and opportunities. Int. J. Appl. Earth Observ. Geoinform., 64: 62-86. https://doi.org/10.1016/j.jag.2017.09.005

Ozturk, H.H. and Bascetincelik, A. 2006. Energy exploitation of agricultural biomass potential in Turkey. Energy Explor. Exploit., 24(4-5): 313-330. https://doi.org/10.1260/014459806779398802

Provincial Planning and Development Office 2018. Bohol Island Power Development Plan (BIPDP). http://www.ppdobohol.lgu.ph/plan-reports/development-plans/bohol-island-power-development-plan-bipdp/ (accessed September 2020).

Rahman, M.M. and Paatero, J.V. 2012. A methodological approach for assessing the potential of sustainable agricultural residues for electricity generation: South Asian perspective. Biomass Bioenrg., 47(0): 153-163. https://doi.org/10.1016/j.biombioe.2012.09.046.

Riva, G., Foppapedretti, E. and Caralis, C. 2014. Handbook on Renewable Energy Sources- Biomass Energy Supply.

Singh, J. 2015. Overview of the electric power potential of surplus agricultural biomass from an economic, social, environmental and technical perspective: A case study of Punjab. Renew. and Sust. Energ Rev., 42: 286-297.

https://doi.org/10.1016/j.rser.2014.10.015.

Voivontas, D., Assimacopoulos, D. and Koukios, E. G. 2001. Assessment of biomass potential for power production: A GIS-based method. Biomass and Bioenerg., 20(2): 101-112. https://doi.org/10.1016/ S0961-9534(00)00070-2.

Vrieling, A., De Leeuw, J. and Said, M. Y. 2013. Length of the growing period over Africa: Variability and trends from 30 years of NDVI time series. Remote Sens., 5(2): 982-1000. https://doi.org/10.3390/rs5020982.

Zhu, Z., Bi, J., Pan, Y., Ganguly, S., Anav, A., Xu, L., Samanta, A., Piao, S., Nemani, R. R. and Myneni, R. B. 2013. Global data sets of vegetation leaf area index (LAI) $3 \mathrm{~g}$ and fraction of photosynthetically active radiation (FPAR)3g derived from global inventory modeling and mapping studies (GIMMS) normalized difference vegetation index (NDVI3G) for the period 1981 to 2. Remote Sens., 5(2): 927-948. https://doi. org/10.3390/rs5020927. 